\title{
Does Corruption Lead to Lower Subnational Credit Ratings? Fiscal Dependence, Market Reputation, and the Cost of Debt
}

\author{
Maciej Sychowiec* (D), Monika Bauhr, (D) and Nicholas Charron \\ Department of Political Science, University of Gothenburg; Gothenburg, Sweden \\ ${ }^{\star}$ Corresponding author: Maciej Sychowiec, Email: maciej.sychowiec@gu.se
}

\begin{abstract}
While studies show a consistent negative relationship between the level of corruption and range indicators of national-level economic performance, including sovereign credit ratings, we know less about the relationship between corruption and subnational credit ratings. This study suggests that federal transfers allow states with higher levels of corruption to retain good credit ratings, despite the negative economic implications of corruption more broadly, which also allows them to continue to borrow at low costs. Using data on corruption conviction in US states and credit ratings between 2001 and 2015, we show that corruption does not directly reduce credit ratings on average. We find, however, heterogeneous effects, in that there is a negative effect of corruption on credit ratings only in states that have a comparatively low level of fiscal dependence on federal transfers. This suggest that while less dependent states are punished by international assessors when seen as more corrupt, corruption does not affect the ratings of states with higher levels of fiscal dependence on federal revenue.
\end{abstract}

Keywords: fiscal dependence; the United States; corruption; subnational credit ratings

\section{Introduction}

During the last few decades, international organizations, policy makers, and experts have expressed an increased concern about the negative economic effect of corruption. While early studies seem to indicate that corruption may help business navigate red tape and thereby improve economic performance, ${ }^{1}$ the balance of evidence to date suggests that the negative economic consequences outweigh any potential benefits. ${ }^{2}$ Corruption reduces government revenue from taxable sources, ${ }^{3}$ increases government expenditures by reducing the productivity of government spending, ${ }^{4}$ decreases the rate of growth, ${ }^{5}$ and increases public deficits ${ }^{6}$ and public debt. ${ }^{7}$ International credit rating agencies, such as Standard \& Poor's and Moody's, have also been sensitive to the fact that "institutions matter" for economic performance, ${ }^{8}$ and some agencies even incorporate widely used cross-country comparative measures of corruption in their sovereign credit rating indices. ${ }^{9}$ Studies suggest that corrupt countries receive lower credit ratings, ${ }^{10}$ which increases the cost of borrowing. With few notable exceptions, ${ }^{11}$

\footnotetext{
${ }^{1}$ Leff, 1964.

${ }^{2}$ Sharma and Mitra, 2019.

${ }^{3}$ Imam and Jacobs, 2007; Litina and Palivos, 2016; Baum et al., 2017; Liu and Mikesell, 2014.

${ }^{4}$ Mauro, 1998.

${ }^{5}$ Del Monte and Papagni, 2007; Mauro, 1995; Mo, 2001; Tanzi and Davoodi, 2002; Rajkumar and Swaroop, 2008 ; Aidt, 2009.

${ }^{6}$ Oto-Peralias, Romero-Avila, and Usabiaga, 2013.

${ }^{7}$ Coorey et al., 2017; Liu et al., 2017; Benfratello et al., 2018.

${ }^{8}$ North, 1981.

${ }^{9}$ Panizza, 2017.

${ }^{10}$ Butler et al., 2009; Mellios and Paget-Blanc, 2006; Connolly, 2007; Afonso et al., 2011; Biglaiser and Staats, 2012; Ozturk, 2014.

${ }^{11}$ Depken and Lafountain, 2006; Butler et al., 2009; Bastida et al., 2015; Pérez-Balsalobre and Llano-Verduras, 2020.
} 
however, studies on the link between corruption and credit ratings have been at the national level. Thus, despite the growing levels and importance of subnational borrowing, ${ }^{12}$ in addition to well documented subnational variation in corruption and quality of institutions, ${ }^{13}$ we know comparatively little about the effect of corruption on subnational credit ratings.

This paper suggests that corruption does not reduce credit ratings to an equal extent across all US states, and, therefore, that the link between corruption and credit ratings is far from as straightforward as previous studies suggest. Specifically, we suggest that the credit ratings of states that receive higher levels of federal fiscal transfers, are largely unaffected by higher levels of corruption. Fiscal dependence on the federal government thereby seems to provide the kind of debt repayment guarantee that states need in order to maintain a good credit reputation, despite the fact that political corruption fuels the misallocation of government funds and tends to lead to lower ratings at the national level. If credit rating agencies perceive fiscal dependence as a guarantee of debt repayment, ${ }^{14}$ and therefore refrain to punish the fiscal excesses of corrupt states, corrupt states are allowed to continue to borrow on favorable terms.

Using data on corruption convictions in US states and bond ratings between 2001 and 2015, we show that corruption does not directly reduce subnational credit ratings on average. The effects of corruption on subnational credit ratings are, however, heterogeneous, and vary depending on a state's level of fiscal dependence on the central government. Empirically, we find a negative effect of corruption on credit ratings only in states that receive a comparatively low level of federal transfers.

We thereby seek to make several contributions to the literature on corruption and credit ratings. First, our focus on the subnational level offers several advantages. As noted by studies on subnational debt, the subnational level is important because of its growing level of borrowing, ${ }^{15}$ but also because this level of government is often closely involved in public service delivery. Cutting expenditures often has important consequences in the form of abandoned infrastructure projects, or layoffs of social workers, teachers, and police officers. Despite this, we know comparatively little on the link between corruption and credit ratings at the subnational level. Our sample also provides ample variation on our key variables both across US states, as well as within them over time. More importantly, the subnational analysis might provide a more valid comparison of the dynamics at play across units, as many unobserved cultural and institutional factors are "naturally controlled for" when comparing units within countries. ${ }^{16}$ Moreover, our focus also allows us to use objective data on corruption levels rather than measures based on expert perceptions.

Second, to the best of our knowledge, this is the first study that investigates how the overall level of fiscal dependence affects the creditworthiness of corrupt subnational units. We thereby seek to add to the rich literature on fiscal dependence and decentralization. While the debate on whether external aid may or may not produce better economic performance among corrupt governments is ongoing, ${ }^{17}$ the evidence on the beneficial effects of fiscal dependence and decentralization is decidedly mixed. ${ }^{18}$ An important body of work suggests that when central governments commit to substantial co-financing, they are often both constitutionally and politically constrained from ignoring the fiscal problems of subnational units. ${ }^{19}$ In other words, fiscal dependence may lead to bailout expectations and reduced risk of standalone default, at least under some circumstances. ${ }^{20}$ While fiscal guarantees may not be expected in all situations, we suggest that maintaining a high level of fiscal transfers despite higher levels of corruption or economic mismanagement can send a strong signal to rating agencies about

\footnotetext{
${ }^{12}$ Ahrend et al., 2013.

${ }^{13}$ Charron et al., 2014.

${ }^{14}$ Rodden, 2006; Von Hagen and Eichengreen, 1996.

${ }^{15}$ Ahrend et al., 2013.

${ }^{16}$ Snyder, 2001.

${ }^{17}$ Svensson, 1999; Asongu and Jellal, 2013.

${ }^{18}$ e.g., Rodden, 2002; Rodríguez-Pose and Krøijer, 2009; Martinez-Vazquez et al., 2017; Fisman and Gatti, 2002.

${ }^{19}$ Rodden, 2002.

${ }^{20}$ Hanniman (2018) suggests that only stable and predictable payments support local creditworthiness. Some of these related studies do not use credit ratings as their dependent variable but interest rates.
} 
the central government's commitment to act as a guarantor of timely debt repayment. This allows corrupt states to maintain favorable ratings and continue to borrow at low costs.

\section{Corruption, credit ratings, and fiscal transfers}

Credit ratings have an important impact on government's ability to finance its budget. Good credit ratings allow governments to borrow money on more favorable terms. ${ }^{21}$ Credit ratings provide an external expectation on a state's perceived ability and willingness to repay its debts, which best represents our concept of creditworthiness. In particular, at the subnational level where information may be less available, bond credit ratings provide domestic and international investors key additional data used to assess investment strategies. Although they have received ample international critique from a host of critics and scholars, ${ }^{22}$ these ratings remain highly salient to a state's reputation, and changes in ratings often warrant "front page news." ${ }^{\text {,3 }}$ Rating agencies exercise a unique form of market based authority by assigning ratings that determine the creditworthiness of debt issuers, including sovereign governments, and the default risk associated with their bonds. ${ }^{24}$ They have been described as a market actor that combines "the normative market authority and the moral authority of the non-state, non-self interested referee," exercising significant authority in the world economy. ${ }^{25}$ A great amount of scholarly attention has therefore been devoted to analyzing the determinants of credit ratings, and not least political determinants of credit ratings. ${ }^{26}$

The literature on the effect of the quality of institutions, e.g., factors such as corruption or rule of law, have provided evidence that better functioning institutions are strongly associated with higher credit ratings from international assessors. ${ }^{27}$ Scholars have noted that this relationship is due to the decrease in perceived risk of default among countries with better functioning institutions-leaders operating a strong rule of law system with lower corruption are more constrained from malfeasance, which in turn makes their commitments more credible. ${ }^{28}$ Moreover, the cost of publicly funded projects increases if civic servants receive graft, thus increasing debt and reducing a state's capacity to repay. Corrupt governments tend to direct public resources toward sectors that provide the greatest opportunities for rent seeking, such as large capital investments or infrastructure, ${ }^{29}$ rather than the ones that provide the greatest returns for the public good. Corruption also leads to tax evasion, ${ }^{30}$ which further undermines fiscal capacity. Several studies have found that corruption increases investors' uncertainty, and thus leads to higher borrowing costs. ${ }^{31}$

At the country level, the negative relationship between corruption and credit ratings has been consistent across multiple samples and model specifications. ${ }^{32}$ Thus, our data and sample of US states presents an empirical puzzle, which is elucidated in figure 1. On the left side, we plot a measure of (control of) corruption risk on the $x$-axis (from International Country Risk Guide [ICRG]), and the Standard \& Poor's sovereign credit rating on the $y$-axis. As per the previous literature, we observe a strong and positive relationship between these two variables, with the corruption measure explaining 75 percent of the variation in cross-national credit ratings. On the other hand, using data from the same year (2014), we find that our measure of corruption is essentially orthogonal to state-level credit ratings;

\footnotetext{
${ }^{21}$ Kerwer, 2005; Sinclair, 2008.

${ }^{22}$ e.g., Mennillo and Sinclair, 2019.

${ }^{23}$ Abdelal and Blyth, 2015.

${ }^{24}$ Sinclair, 2008.

${ }^{25}$ Cutler, Haufler and Porter, 1999; Hall and Biersteker, 2002.

${ }^{26}$ Cantor and Packer, 1996; Sinclair, 2008; Bruner and Abdelal, 2005; Archer et al., 2007; Biglaiser and Staats, 2012; Barta and Johnston, 2018; Barta and Makszin, 2020.

${ }^{27}$ Mellios and Paget-Blanc, 2006.

${ }^{28}$ Butler et al., 2009.

${ }^{29}$ Tanzi and Davoodi, 2002; Kaufmann, 2001; Liu and Mikesel, 2014.

${ }^{30}$ e.g., Richey, 2010; Matsaganis et al., 2012; Litina and Palivos, 2016; Baum et al., 2017.

${ }^{31}$ Berg et al., 2016; Liu et al., 2017.

${ }^{32}$ Butler et al., 2009; Mellios and Paget-Blanc, 2006; Connolly, 2007; Afonso et al., 2011; Biglaiser and Staats, 2012; Ozturk, 2014.
} 

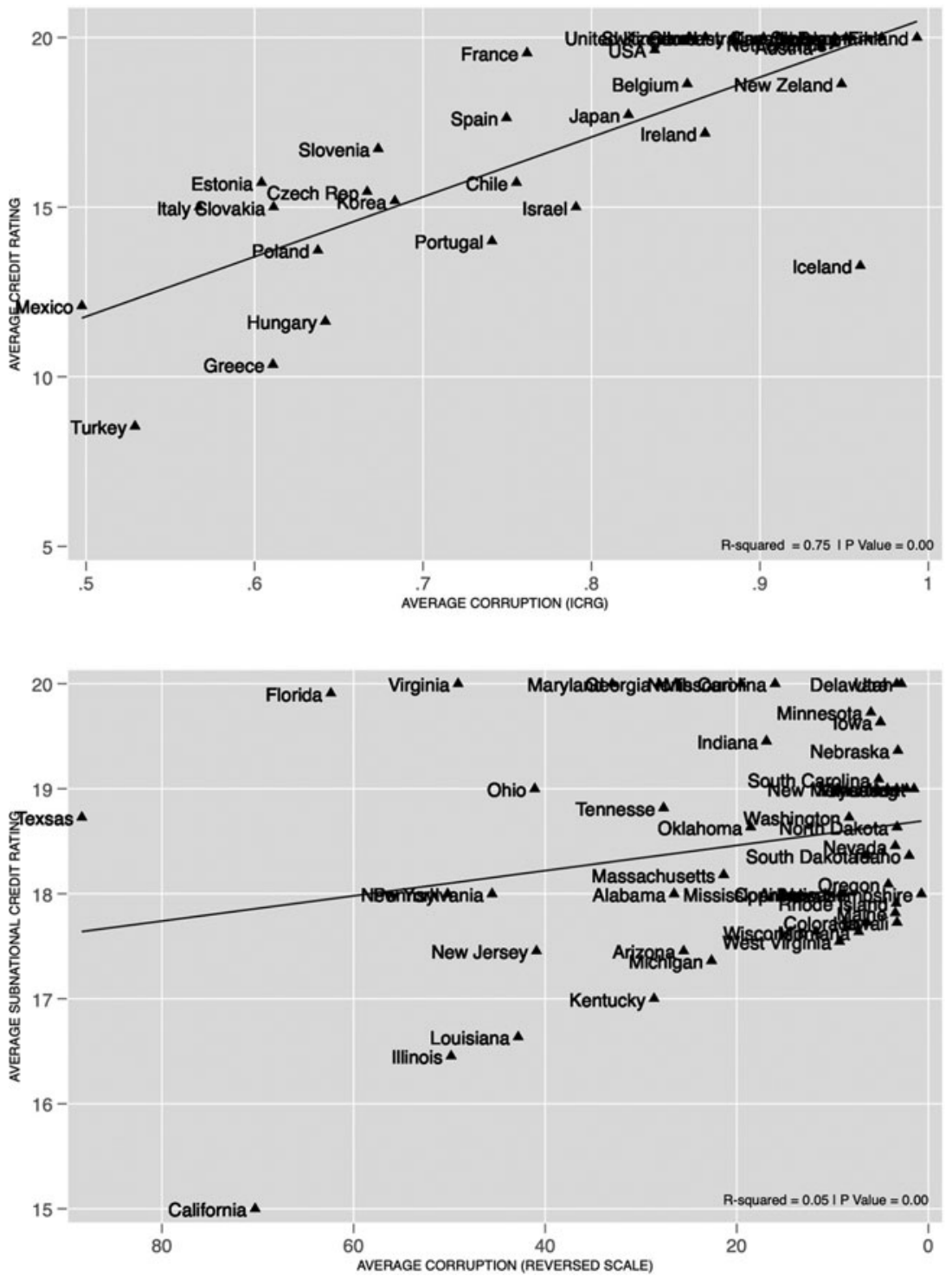

Figure 1. Corruption and credit ratings at two levels of governance: National level (left) and in US states (right)

only explaining 5 percent of the variation $(\mathrm{p}=0.00)$. Our central argument in addressing this puzzle is that the effect of corruption on credit ratings is heterogeneous-conditional on a state's fiscal dependence to the central government.

Thus, the relationship between corruption and credit ratings may not be as straightforward and direct as previous studies suggest. Although fewer studies investigate the effect of corruption on subnational credit ratings directly, a number of studies point to the fact that corruption may undermine credit ratings also at the subnational or municipal level. ${ }^{33}$ In the United States, both Depken and Lafountain (2006) and Butler et al. (2009) show that corruption is associated with lower subnational credit ratings.

\footnotetext{
${ }^{33}$ Hernandez-Trillo and Smith-Ramirez, 2009; Bastida et al., 2015. Hanniman (2018) suggests that only stable and predictable payments support local creditworthiness. Some of these related studies do not use credit ratings as their dependent variable but interest rates."
} 
However, despite the fact that claims related to the negative effect of corruption on a range of economic variables, including credit ratings, enjoy considerable empirical support and theoretical clout, these results do not necessarily hold across time and space at the subnational level. Building on the vast literature on fiscal dependence and decentralization, we suggest that one factor that may contribute to maintaining good credit ratings among corrupt subnational units is the relative level of fiscal transfers and fiscal dependence. A broad body of studies suggest that fiscal dependency fuels bailout expectations, and that government that co-finances the budget of subnational units will signal both ability and willingness to repay debts. ${ }^{34}$ Rodden $(2002,670)$ highlights this key dilemma of fiscal federalism and contends that when "constitutionally or politically constrained central governments take on heavy co-financing obligations, they often cannot credibly commit to ignore the fiscal problems of lower level government." Moreover, Rodden (2006) notes explicitly that international ratings agencies grade lesser developed regions more favorably when the federal government has an established equalization system of transfers across subnational units, in that "they provide a safety net of varying importance during difficult times." 35 Other studies, similarly argue that fiscal dependence may create bailout expectations and implicitly guarantee debt repayment. This compensation effect is driven by federal governments' wish to maintain their own ratings as well as avoid being punished by the electorate for failures in local public service delivery. ${ }^{36}$ Subnational creditworthiness becomes less about the solvency of the subnational borrower and more about the creditworthiness of the implicit guarantor-the federal government in this case. ${ }^{37}$ Thus, we suggest that a higher degree of federal dependence serves as a buffer mechanism against the negative effect of corruption on subnational credit ratings. In turn, the effect of corruption is anticipated to be heterogeneous-dependent on the level of federal dependence-not direct, as suggested by previous studies.

A simple two-state comparison with similar, high-profile corruption cases provides an illustrative example of our main point. On the one hand, the state of Illinois is, and has been, one of least dependent states on federal transfers, ranking usually in the bottom third of all states in terms of budget dependence annually. In 2008, former governor Rod Blagojevich was implicated in a corruption scandal where he attempted the sale of then Senator Obama's senate seat, along with extortion and lying to federal agents, which resulted in a conviction and prison sentence for Blagojevich. The corruption conviction in this case led to a near immediate downgrade from Standard \& Poor's in the following year of 2009. On the other hand, Alabama is a state that is highly dependent on annual federal transfers, usually in ranking among the top 10 percent of states annually. However, a 2006 conviction of former governor Don Siegelman on several counts of bribery and obstruction led to no subsequent change in Alabama's credit rating.

This leads to the following two hypotheses:

\section{H1. Corruption does not have a direct effect on subnational credit ratings in the United States.}

H2. Corruption has a negative effect on credit ratings only in states with low levels of fiscal dependence.

\section{Sample and data}

Our empirical hypotheses are tested via a subnational analysis of US states from 2001-15. This sample offers several key advantages to test the hypotheses put forth in this study. First, the subnational analysis allows us to "naturally control for" unobserved cultural and institutional factors, which can lead to a more valid comparison. ${ }^{38}$ Second, as we show in this section, there is ample variation on our key variables both across states, as well as within with them. Third, with some notable exceptions ${ }^{39}$

\footnotetext{
${ }^{34}$ Rodden 2002, 2006; Rodden, Eskeland, and Litvack, 2003; Ahrend, 2012; Wildasin, 2004; Bordignon and Turati, 2009; Vigneault, 2010; Escolano et al., 2012.

${ }^{35}$ Standard \& Poor's, 2002, 7.

${ }^{36}$ Enderlein et al., 2010, 423-37.

${ }^{37}$ Hallerberg, 2011; Rodden, 2006.

${ }^{38}$ Snyder, 2001.

${ }^{39}$ Depken and Lafountain, 2006; Butler et al., 2009; Pérez-Balsalobre and Llano-Verduras, 2020.
} 
most of the literature on the relationship between institutional quality and credit ratings is at the country-level, our study provides a clear empirical compliment.

\section{The dependent variable}

The outcome variable of this study is bond credit rating of US states between 2001 and 2015 . Rather than using actual debt or default or interest rates, the credit rating represents the expert, external expectation of a state's ability and willingness to repay its debt, which best represents our concept of creditworthiness. In particular, at the subnational level, where information may be less available, bond credit ratings provide domestic and international investors key additional data used to assess investment strategies. Although ratings have not been without controversy ${ }^{40}$ these ratings provide valuable information to the credit market ${ }^{41}$ and remain highly salient to a state's reputation. ${ }^{42}$

While all of the "big three" agencies (Standard \& Poor, Moody's, and Fitch) rate some states in some years, only Standard \& Poor provide data for all states over a significant time period annually, and thus we elect to use their measure to maximize our sample coverage. ${ }^{43}$ The corresponding ratings among the three agencies for available states is remarkably high, however. ${ }^{44}$ The Standard \& Poor ratings are on a possible 23-point scale, with the coveted "AAA" rating being the max value (representing the highest assessment of creditworthiness) and "SD" being the lowest (the lowest assessment of creditworthiness), with higher scores resulting in a lower interest rate on debt. Similar to previous studies, we transform the ratings into an ordinal scale. As most state-years are at least a grade of "A" or above (save Illinois and California for two and three years, respectively), the "effective" range of our sample is a 6-point scale, with higher values equating to high levels of creditworthiness. Thus, while US municipalities may default on their debt, it is important to note that US states have not historically defaulted.

Although the grand mean of our outcome variable is relatively stable over time in our sample, we do observe temporal changes in ratings in 36 of the 50 states ( 72 percent) and the cross-sectional variation is noteworthy, with some states achieving and maintaining top ratings, while others are rated significantly lower. Figure 2 shows the average rating score by US state for our time period, with lighter shades equating to better average ratings:

\section{Corruption}

Corruption is defined most commonly as "the abuse of public office for private gain." ${ }^{45}$ However, due to the clandestine nature of the act, it is all but impossible to measure directly, thus contemporary measures (whether "objective" or "subjective" ones) are indirect measures. The literature on corruption's effect on credit ratings varies depending largely on the level of analysis, mainly due to lack of data available across multiple levels of governance. For example, cross-country level studies mainly employ expert assessment measures, such as Transparency International's Corruption Perceptions Index or the World Governance Indices. ${ }^{46}$ Yet for subnational level analysis, these expert perceptions measures are not available to the same degree as the country level. Moreover, such expert-based perceptions measures are highly problematic in explaining credit and bond ratings, as Panizza $(2017,27)$ shows;

\footnotetext{
${ }^{40}$ e.g., Mennilo and Sinclair, 2019.

${ }^{41}$ http://doi.wiley.com/10.1002/ijfe.1461; Cavallo et al., 2013.

${ }^{42}$ Abdelal and Blyth, 2015.

${ }^{43}$ Pew Research, 2017.

${ }^{44}$ Johnson and Kriz, 2005. According to United States's Securities and Exchange Commission, Standard \& Poor's and Moody's control 83 percent of credit-rating market (2019). While these two agencies use different methodologies, correlation between ratings from these two agencies is 0.98 (Hanniman, 2018). Thus, Standard \& Poor's credit ratings are highly correlated with ratings of other agencies, especially Moody's (Caouette et al., 2008).

${ }^{45}$ World Bank, 1997.

${ }^{46}$ Mellios and Paget-Blanc, 2006; Butler et al., 2009; Connolly, 2007; Depken et al., 2006; Afonso et al., 2011.
} 


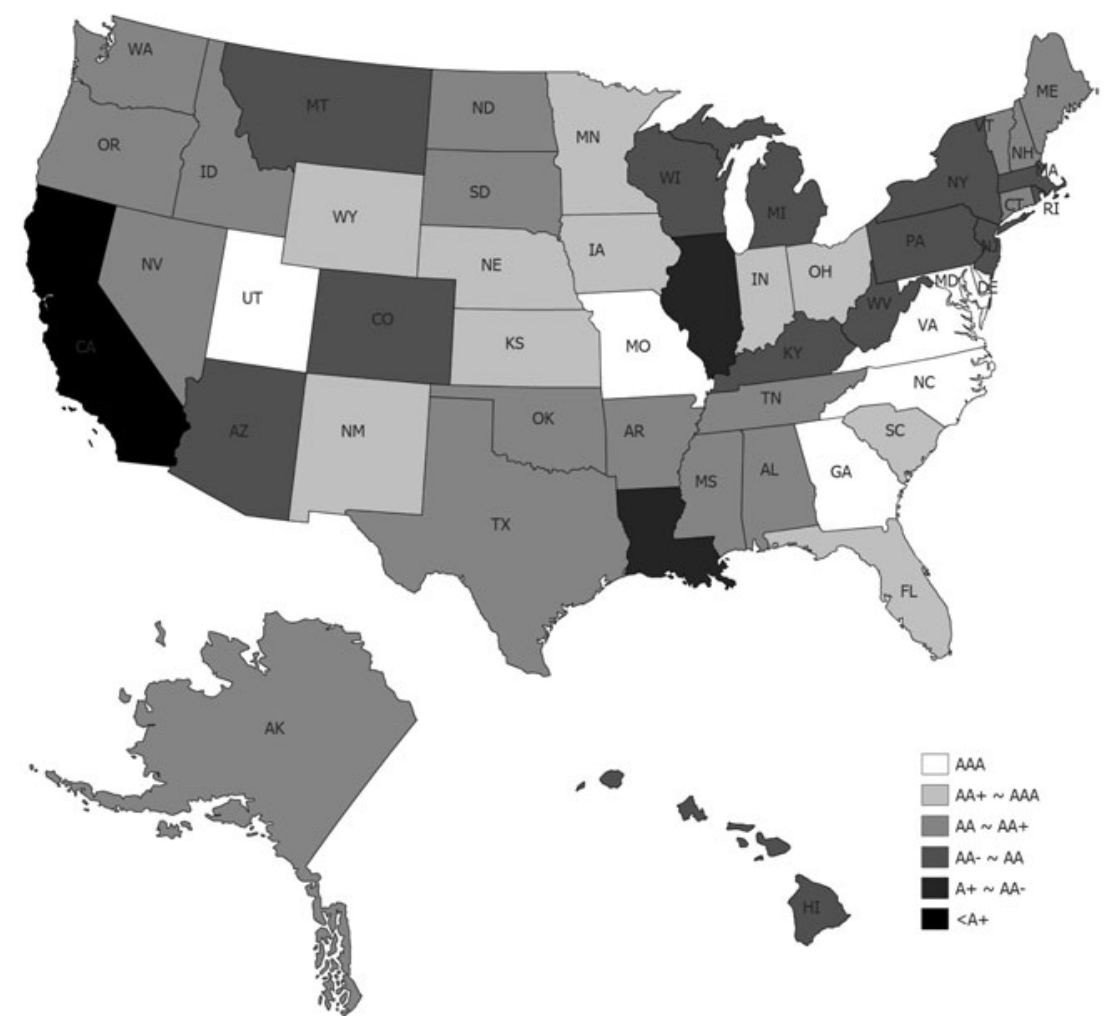

Figure 2: Average state Standard \& Poor credit ratings (2001-15)

sovereign raters such as Moody's and Fitch actually incorporate the World Governance Indicator of corruption in their ratings scores, thus such measures introduce endogeneity, per definition. And, for US states, such data is only available for a single year. ${ }^{47}$

We therefore rely on an objective measure of corruption convictions commonly employed in subnational studies of US states. ${ }^{48}$ Our measure is federal convictions for all federal, state, and local public officials for each state-year from 2001-15 as reported by Public Integrity Section (PIS), who define corruption similar to the literature as, "crimes involving abuses of the public trust by government officials." These convictions include various forms of corruption including accepting bribes, awarding government contracts to vendors without competitive biddings, fraud or campaign-finance violations, and obstruction of justice. For purposes of comparability, we take the per capita (100,000 inhabitants) number of PIS reported convictions. We find considerable variation across states in this measure, with South Dakota and Louisiana reporting roughly 1 corruption conviction per 100,000 inhabitants, while Utah and Oregon have just 0.10 , and New Hampshire just 0.05 convictions per 100,000 residents. We find, however, that observations on the high end of this measure constitute significant leverage outliers (> 3 standard deviations above the variable mean). Thus, to deal with the skewed nature of the distribution of the variable and to avoid misleading findings from such outlying observations, we transform this measure to the cube root, as previous studies have done to adjust for this issue. ${ }^{49}$

One might express concern over the validity of an objective proxy of corruption, such as convictions, which could simply be measuring rule of law enforcement or differences in media oversight. However, Liu et al. (2017) show that such data is not statistically associated with state-level capacity factors, such as caseloads, number of judges, or state judiciary expenditures, thus alleviating some

\footnotetext{
${ }^{47}$ e.g., Boylan and Long, 2003.

${ }^{48}$ Fisman and Gatti, 2002; Glaeser and Saks, 2006; Depken and Lafountain, 2006; Liu et al., 2017.

${ }^{49}$ See Alt and Lassen, 2006.
} 
of these concerns. ${ }^{50}$ Some scholars argue that using federal convictions for subnational data may be problematic because nonfederal officials commit different crimes than federal ones. ${ }^{51}$ However, using federal convictions ensures that the laws under which convictions occur are uniform across different states, ${ }^{52}$ and the measure is a consistent metric over time, as opposed to perceptions measures, which are far less certain in terms of temporal comparisons. Finally, as the literature on US state-level corruption uses this measure consistently, our use of convictions data allows for a more valid comparison of our results with previous studies.

\section{Fiscal dependence}

Our measure of fiscal dependence is the total amount of federal revenue to the state, most of which is in the form of grants, divided by the total amount of state revenue annually. Data are taken from the US Census Bureau's Annual Survey of State Government Finances and Annual Survey of State and Local Government Finances and organized by PEW research. ${ }^{53}$ The measure aggregates all types of federal transfers that complement a state's budget in paying for health services, such as Medicaid, education and training programs, transportation, and infrastructure. The transfer system is largely progressive, with poorer states receiving a greater proportion of their budgets from federal revenues on average, yet the correlation between federal dependence and GDP per capita is -0.53 , and thus economic development does not exclusively explain a state's level of dependence. The measure also captures the stable, annual equalizing payments that are argued to be more important for international creditworthiness of subnational actors. ${ }^{54}$

The data show remarkable variation across states. ${ }^{55}$ For example, in our latest year (2015), Virginia and Hawaii receive 22 and 23 percent of their budget respectively from federal revenues, while Louisiana and Mississippi rely on roughly double that percentage, over 42 percent, respectively. We also see significant changes over time within states. For example, the dependence on federal revenues in Arizona went from just 30 percent in 2008 to 46 percent in 2010, a much larger increase from the national average of 28 percent to 35 percent during the same period. The share of Kansas's federal revenues has dropped to under 25 percent since the 2009 recession, while in Kentucky; dependence on federal transfers increased to over 40 percent and have remained roughly so since.

\section{Additional controls}

As our study employs observational data, we add additional control variables to our model to reduce the possibility of drawing invalid inferences from a spurious relationship between our main variables of interest. We are particularly interested in factors that can confound our relationship between corruption and credit ratings, along with the conditional effects based on transfers. In the literature, such standard controls include gross public debt as percentage of GDP, GDP per capita, unemployment, total spending as \% GDP, the population of a state. ${ }^{56}$ Based on previous findings, we anticipate that all control variables, save GDP growth, GDP per capita, and the size of population, have a negative effect on the ability to debt repayment, thus we anticipate negative coefficients for credit ratings. Moreover, our models control for the amount of economic freedom in a state (from the Cato Institute ${ }^{57}$ ),

\footnotetext{
${ }^{50}$ However, Alt and Lassen (2012) show that greater prosecutor resources result in more convictions for corruption, though caseload itself may not influence the outcome of particular case.

${ }^{51}$ Cordis and Milyo, 2016.

${ }^{52}$ Depken and Lafountain, 2006.

${ }^{53} \mathrm{https} / / /$ www.pewtrusts.org/en/research-and-analysis/data-visualizations/2014/fiscal-50\#ind1.

${ }^{54}$ Hanniman, 2018.

${ }^{55}$ In appendix $\mathrm{G}$ we provide more detailed discussion about federal transfers. We discuss the consistency of federal transfers over time. In addition, we provide bivariate relationship between federal transfers and credit ratings.

${ }^{56}$ Cantor and Packer, 1996; Archer et al., 2007; Depken and Lafountain, 2006.

${ }^{57}$ The variable is a composite index of a host of factors representing fiscal and regulatory freedom of a state, annually (https:// www.freedominthe50states.org/). We thank an anonymous reviewer at Business and Politics for this suggestion.
} 
which proxies for the overall business climate in a state. Summary statistics for all variables are found in the appendix A.

\section{Diagnostics tests and estimation strategy}

In the literature, credit ratings are modeled in several ways. First, some scholars elect to use either tobit estimation, ${ }^{58}$ or ordered probit/logit ${ }^{59}$ due to the limited, ordered nature of the measure. Others choose to model variation in credit ratings continuously, via linear regression. ${ }^{60}$ While exact model predictions would be expected to vary based on the estimation choice, these approaches produce similar substantive effects irrespective of this decision, thus we present linear models for simplicity, with alterative estimations in appendix F.

As our data is time series cross-sectional (TSCS), we perform the standard diagnostic tests of problems commonly associated with such data. A Dickey-Fuller test for stationarity shows no unit root in the dependent variable, implying that the sample mean and variance do not significantly vary over time. However, we find the presence of positive serial correlation and heteroscedasticity in the data, and thus similar to most previous panel data studies, ${ }^{61}$ we employ dynamic models with a lagged dependent variable and robust standard errors, clustered by states. To arrive at the proper lag structure for the dependent variable, we follow Hendry (1995) and "test down" (via cs) to assess how many lags to include, which in our case is one lag.

We account for the unit heterogeneity of states over time and omitted, time-invariant variables from the model in several ways to test the consistency of our findings. First, a Hausman test favors fixed effects models, which account for the within-state variation of the dependent and explanatory variables. Our fixed effects estimation to test $\mathrm{H} 1$ is thus the following:

$$
C R_{i t}-\overline{C R}_{i}=\beta_{1}\left(C_{i t}-\bar{C}_{i}\right)+\sum_{k=1}^{k} \beta_{k}\left(\delta_{k i t}-\bar{\delta}_{k i}\right)+u_{i}-\bar{u}_{i}+\epsilon_{i t}-\bar{\epsilon}_{i}
$$

Where credit ratings in each state-year $\left(C R_{i t}\right)$ are explained by corruption $(\mathrm{C})$ and a ' $\mathrm{k}$ ' number of covariates, $\delta_{i t}$, which includes a lagged dependent variable $\left(C R_{i t-1}\right){ }^{62} u_{i}$ are the state-specific, timeinvariant effects, and $\epsilon_{i t}$ is our error term. The fixed effects transformation subtracts the within-unit average from each observation for each time point, and thus washes out unit specific effects, and also drops time invariant covariates.

However, as our effective time series is fifteen years, a somewhat short period to analyze relatively slow moving variables such as credit ratings and corruption, relying on solely within-state variation provides a 'tougher test' and oftentimes less efficient estimates. ${ }^{63}$ As the between-state variation in the dependent variable is more than twice that of the average within-state variation, we present partialpooled and pooled models with alternative estimators to incorporate more directly this between-state variation. Thus, second, we report random intercept models. However, it is well understood that the inclusion of a lagged dependent variable in a random effects model violates a key assumption of the model, in that the random intercept $\left(\mu_{i}\right)$, which represents the unobserved state-level, static variables, is assumed to be orthogonal with the independent variables on the right side of the model. Yet the inclusion of a lag of our outcome variable, credit ratings, on the right side $\left(C R_{i t-1}\right)$ is necessarily correlated with $\mu_{i}$ and will bias $C R_{i t-1}$ upward and estimates of other explanatory variables downward. ${ }^{64}$

\footnotetext{
${ }^{58}$ Depken and LaFountain, 2006.

${ }^{59}$ Grizzle, 2010; Pérez-Balsalobre and Llano-Verduras, 2020.

${ }^{60}$ Hanniman, 2018; Archer et al., 2007; Cantor and Packer, 1996.

${ }^{61}$ See Biglaiser et al., 2008; Liu et al., 2017.

${ }^{62}$ The inclusion of lagged dependent variable is a standard procedure in studies on credit ratings (e.g., Biglaiser and Staats, 2012; Shea and Solis, 2018).

${ }^{63}$ Troeger, 2019.

${ }^{64}$ Allison et al., 2017.
} 
To address this issue, we provide our random effects estimates based on a technique based on Anderson-Hsiao (1981), which is developed for dynamic panel models via the use of an instrumental (IV) estimator. In this case, we employ the second lag of the dependent variable $\left(C R_{i t-2}\right)$, which is exogenous to $\mu_{i}^{65}$ when controlling for the first lag. The generalized, two-stage estimator (G2SLS) is particularly appropriate when the number of units is relatively large and the number of time units are relatively small, and no second-order autocorrelation, as in our case.

For example, our model specification to test $\mathrm{H} 2$ with this estimation is as follows:

$$
C R_{i t}=\alpha+\beta_{1}\left(C R_{i t-1}\right)+\beta_{2}\left(C_{i t}\right)+\beta_{3}\left(T_{i t}\right)+\left(\beta_{4}\left(C * T_{i t}\right)\right)+\delta k_{i t}+\mu_{i}+\epsilon_{i j}
$$

Where the following first stage estimates are:

$$
C R_{i t-1}=\alpha+\beta_{1}\left(C R_{i t-2}\right)+\theta k_{i t}+\mu_{i}+\epsilon_{i j}
$$

Where we run a first stage model in which the lag of our dependent variable $\left(C R_{i t-1}\right)$ is instrumented with the second lag $\left(C R_{i t-2}\right)$, along with the battery of " $k$ " number of explanatory variables $\left(\theta k_{i t}\right)$ in the second stage model. In the second stage model, we then regress credit ratings $C R_{i t}$ on its first year lag (modeled as endogenous), along with the main variables of interest (corruption and transfers), and to test $\mathrm{H} 2$, we include $\beta_{4}$ to test the interaction. $\delta k_{i t}$ represents our battery of control variables, while $\mu_{i}$ is the random intercept for each state and $\epsilon_{i j}$ is our model error term. Since credit rating agencies can react with a rating changes at any time (they do not have to wait to the end of a fiscal year, for example) we model our explanatory variables as in the same time as the outcome variable, with the exception of growth, which we expect to have a time lagged effect.

Finally, we use Prais-Winsten models, adjusting for first order autocorrelation and panel corrected standard errors, ${ }^{66}$ to provide further robustness checks of our FE and RE estimation.

\section{Results}

We begin with a set of models to test the first hypotheses in table 1-that of the direct effect of corruption on credit ratings. The first two models show the within estimates from the fixed effects models, while models 3 and 4 show the random effect generalized IV estimates. Model 5 presents the pooled Prais-Winsten (PW) estimates without a lagged dependent variable, adjusting for first order autocorrelation and includes state-clustered standard errors. We find, in fact, a consistent small, positive effect of state-level corruption on our outcome variable, yet in all models, the effect is statistically negligible. Overall, however, we find no evidence of a direct effect of corruption on state-level credit ratings, which supports our H1. However, this finding runs contrary to the earlier findings of Depken and Lafountain (2006). This discrepancy could be due to their analysis relying on a different set of control variables, an earlier time period (1995-2000), as well as using a pooled linear estimation model, which does not account for structural heterogeneity across states, which we model directly. Another reason could be that rating agencies do not have fixed criteria of assessment over time ${ }^{67}$ and the global financial crisis could play a significant role in shaping these new criteria.

In $\mathrm{H} 2$, we posit that corruption has heterogonous effects on our dependent variable, depending on levels of fiscal dependence. In table 2, we provide a similar set of estimation strategies in models $1-5$ as per table 1 .

The interaction term is the coefficient of interest, as this provides the test of whether the effect of corruption on credit ratings changes significantly as a function of fiscal dependence. In this case, we find quite consistent results across the models that adjust for different estimators and specification of control variables. The models reveal that the interaction is positive in all cases, implying that corruption's effect on our dependent variable in fact increases positively as a function of higher levels of fiscal

\footnotetext{
${ }^{65}$ Baltagi, 2013.

${ }^{66}$ Beck and Katz, 1995.

${ }^{67}$ Standard \& Poor's, 2008.
} 
Table 1: Test H1 - The relationship between corruption and subnational creditworthiness

\begin{tabular}{|c|c|c|c|c|c|}
\hline & \multicolumn{2}{|c|}{ Fixed Effects } & \multicolumn{2}{|c|}{ REG2SLS } & \multirow{2}{*}{$\begin{array}{c}\text { Prais Winsten } \\
5\end{array}$} \\
\hline & 1 & 2 & 3 & 4 & \\
\hline \multirow[t]{2}{*}{ Corruption } & 0.030 & 0.046 & -0.003 & 0.034 & 0.051 \\
\hline & $(0.088)$ & $(0.066)$ & $(0.094)$ & $(0.072)$ & $(0.048)$ \\
\hline \multirow[t]{2}{*}{ Federal dependence } & & -0.950 & & $-0.970^{\star}$ & $-1.316^{\star}$ \\
\hline & & $(0.604)$ & & $(0.575)$ & $(0.720)$ \\
\hline \multirow[t]{2}{*}{ Credit rating (t-1) } & $0.845^{\star \star \star}$ & $0.793^{\star * \star}$ & $0.831^{\star \star \star}$ & $0.797^{\star \star \star}$ & \\
\hline & $(0.040)$ & $(0.042)$ & $(0.044)$ & $(0.046)$ & \\
\hline \multirow[t]{2}{*}{ Unemployment } & & $-0.067^{\star \star}$ & & $-0.078^{\star \star \star}$ & 0.012 \\
\hline & & $(0.025)$ & & $(0.028)$ & $(0.020)$ \\
\hline \multirow[t]{2}{*}{ GDP growth (t-1) } & & -0.001 & & -0.001 & 0.003 \\
\hline & & $(0.003)$ & & $(0.003)$ & $(0.002)$ \\
\hline \multirow[t]{2}{*}{ Economic Freedom } & & $0.870^{\star \star \star}$ & & $0.715^{\star \star}$ & $0.770^{\star \star \star}$ \\
\hline & & $(0.317)$ & & $(0.309)$ & $(0.208)$ \\
\hline \multirow[t]{2}{*}{ Spending/GDP } & & -0.026 & & -0.022 & -0.012 \\
\hline & & $(0.019)$ & & $(0.017)$ & $(0.010)$ \\
\hline \multirow[t]{2}{*}{ Debt/GDP } & & -0.004 & & -0.008 & $-0.027^{\star \star}$ \\
\hline & & $(0.012)$ & & $(0.014)$ & $(0.011)$ \\
\hline \multirow[t]{2}{*}{ GDP (logged, p.c.) } & & 0.161 & & -0.021 & -0.175 \\
\hline & & $(0.405)$ & & $(0.401)$ & $(0.301)$ \\
\hline \multirow[t]{2}{*}{ Population (logged) } & & 0.013 & & -0.002 & -0.010 \\
\hline & & $(0.028)$ & & $(0.029)$ & $(0.021)$ \\
\hline \multirow[t]{2}{*}{ Constant } & $2.927^{\star \star \star}$ & 2.942 & $3.109^{\star \star \star}$ & 5.199 & -23.494 \\
\hline & (0.729) & (4.407) & $(0.794)$ & (4.417) & (28.522) \\
\hline
\end{tabular}

\begin{tabular}{|c|c|c|c|c|c|}
\hline Instrument & & & $C R_{i t-2}$ & $C R_{i t-2}$ & \\
\hline Durbin Watson (orig.) & & & & & 0.15 \\
\hline Durbin Watson (adj.) & & & & & 1.66 \\
\hline Obs. & 731 & 726 & 681 & 676 & 732 \\
\hline Within $\mathrm{R}^{2}$ & 0.713 & 0.731 & 0.716 & 0.733 & \\
\hline Between $\mathrm{R}^{2}$ & 0.991 & 0.926 & 0.991 & 0.944 & \\
\hline $\mathrm{R}^{2}$ total & 0.921 & 0.883 & 0.925 & 0.899 & 0.915 \\
\hline
\end{tabular}

Note: Dependent variable is subnational credit ratings with clustered standard errors by state are in parenthesis. All models include time (year) fixed effects. Models 1 and 2 are fixed effects (within) estimate, while models 3 and 4 use a generalized, 2-stage random effects estimation (REG2SLS), in which the lagged dependent variable is instrumented with its second order lag (first stage estimates shown only). Model 5 is a pooled Prais-Winsten model, adjusting for first order autocorrelation and includes state-clustered standard errors. Durbin-Watson statistics range from 0-4, with "2" indicating no autocorrelation, and show the original (orig) and the model transformed (adj) statistics. All models account for year effects in credit ratings.

${ }^{\star \star \star} p<0.01,{ }^{\star \star} p<0.05,{ }^{\star} p<0.1$.

dependence. The effect is robust to specification and control variables. In all models $1-4$, the effect is statistically significant irrespective of specification. In the pooled Prais -Winsten estimation in model 5, the effect falls short of the 90 percent level of confidence $(\mathrm{p}=0.11)$. Yet the Durbin-Watson statistic indicates there is even some positive autocorrelation present in the model post-adjustment, which 
Table 2: Test of $\mathrm{H} 2$ - Heterogeneous effects of corruption on credit ratings

\begin{tabular}{|c|c|c|c|c|c|}
\hline & \multicolumn{2}{|c|}{ Fixed Effects } & \multicolumn{2}{|c|}{ REG2SLS } & \multirow{2}{*}{$\begin{array}{c}\text { Prais Winsten } \\
5\end{array}$} \\
\hline & 1 & 2 & 3 & 4 & \\
\hline \multirow[t]{2}{*}{ Corruption } & $-0.802^{\star \star}$ & $-0.610^{*}$ & $-0.663^{\star}$ & -0.568 & -0.355 \\
\hline & $(0.370)$ & $(0.317)$ & $(0.381)$ & $(0.351)$ & $(0.280)$ \\
\hline \multirow[t]{2}{*}{ Federal dependence } & $-3.492^{\star \star \star}$ & $-2.367^{\star \star}$ & $-1.502^{\star \star}$ & $-2.275^{\star \star \star}$ & $-2.198^{\star \star}$ \\
\hline & $(0.810)$ & $(0.917)$ & $(0.706)$ & $(0.863)$ & (1.010) \\
\hline \multirow[t]{2}{*}{ Interaction } & $2.740^{\star \star}$ & $2.119^{\star \star}$ & $2.184^{\star}$ & $1.941^{\star}$ & 1.292 \\
\hline & (1.109) & $(0.961)$ & $(1.122)$ & $(1.022)$ & $(0.824)$ \\
\hline \multirow[t]{2}{*}{ Credit rating (t-1) } & $0.825^{\star \star \star}$ & $0.793^{\star \star \star}$ & $0.965^{\star \star \star}$ & $0.799^{\star \star \star}$ & \\
\hline & $(0.044)$ & $(0.043)$ & $(0.015)$ & $(0.046)$ & \\
\hline \multirow[t]{2}{*}{ Unemployment } & & $-0.066^{\star \star \star}$ & & $-0.078^{\star \star \star}$ & 0.013 \\
\hline & & $(0.024)$ & & $(0.027)$ & $(0.020)$ \\
\hline \multirow[t]{2}{*}{ GDP growth (t-1) } & & -0.002 & & -0.000 & 0.003 \\
\hline & & $(0.003)$ & & $(0.003)$ & $(0.002)$ \\
\hline \multirow[t]{2}{*}{ Economic Freedom } & & $0.850^{\star \star \star}$ & & $0.691^{\star \star}$ & $0.766^{\star \star \star}$ \\
\hline & & $(0.311)$ & & $(0.300)$ & $(0.210)$ \\
\hline \multirow[t]{2}{*}{ Spending/GDP } & & -0.029 & & -0.025 & -0.013 \\
\hline & & $(0.019)$ & & $(0.017)$ & $(0.010)$ \\
\hline \multirow[t]{2}{*}{ Debt/GDP } & & -0.002 & & -0.006 & $-0.028^{\star \star}$ \\
\hline & & $(0.012)$ & & $(0.014)$ & $(0.011)$ \\
\hline \multirow[t]{2}{*}{ GDP (logged, p.c.) } & & 0.067 & & -0.130 & -0.197 \\
\hline & & $(0.427)$ & & $(0.429)$ & $(0.300)$ \\
\hline \multirow[t]{2}{*}{ Population (logged) } & & -0.001 & & -0.017 & -0.014 \\
\hline & & $(0.036)$ & & $(0.037)$ & $(0.026)$ \\
\hline Instrument & & & $C R_{i t-2}$ & $C R_{i t-2}$ & \\
\hline Durbin Watson (orig.) & & & & & 0.18 \\
\hline Durbin Watson (adj.) & & & & & 1.67 \\
\hline \multirow[t]{2}{*}{ Constant } & $4.321^{\star \star \star}$ & 4.609 & $1.085^{\star \star \star}$ & 6.998 & -23.166 \\
\hline & $(0.894)$ & $(4.801)$ & $(0.320)$ & $(4.840)$ & $(28.430)$ \\
\hline Obs. & 726 & 726 & 676 & 676 & 732 \\
\hline Within $\mathrm{R}^{2}$ & 0.713 & 0.733 & 0.711 & 0.732 & \\
\hline Between $\mathrm{R}^{2}$ & 0.980 & 0.923 & 0.993 & 0.941 & \\
\hline $\mathrm{R}^{2}$ total & 0.915 & 0.882 & 0.927 & 0.898 & 0.915 \\
\hline
\end{tabular}

Note: Dependent variable is subnational credit ratings with clustered standard errors by state are in parenthesis. All models include time (year) fixed effects. Models 1 and 2 are fixed effects (within) estimate, while models 3 and 4 use a generalized, 2-stage random effects estimation (REG2SLS), in which the lagged dependent variable is instrumented with its second order lag (first-stage estimates shown only). Model 5 is a pooled Prais-Winsten model, adjusting for first order autocorrelation and includes state-clustered standard errors. Durbin-Watson statistics range from 0-4, with " 2 " indicating no autocorrelation, and show the original (orig) and the model transformed (adj) statistics. All models account for year effects in credit ratings. ${ }^{\star \star \star} p<0.01,{ }^{\star \star} p<0.05,{ }^{\star} p<0.1$. 
affects the efficiency of the standard errors, and could explain the higher p-value. Models 2 and 4 show that the effects are affected by the control variables as magnitude of the integration effects decrease by a magnitude of 0.62 and 0.24 , respectively, yet the effects remain significant and in the expected direction. Models 1 and 2 that provide the within-state estimates from the fixed effects models show the greatest magnitude in terms of this effect. The IV random effects and pooled PW models however show similar substantive effects. Yet as Angrist and Pischke (2008) point out, this discrepancy is common, and in these cases the "true" effect lies between the FE estimate (which is usually too high) and the pooled estimate (which is usually too low). Thus, overall, we interpret this set of results as providing empirical evidence for $\mathrm{H} 2$.

With respect to our control variables, the coefficients are largely in the expected direction according to previous findings from the literature. We find that higher values of unemployment have a negative and significant effect on credit ratings, which is robust across all models. This is similar to previous studies at the US state level ${ }^{68}$ and cross-country analyses. ${ }^{69}$ As anticipated, we find that higher levels of economic freedom are associated with better ratings in most models. We find mixed support that debt is a significant predictor of subnational credit ratings, also consistent with the literature. ${ }^{70}$ Yet the mixed findings across models could be due to various types of debt having heterogeneous effects on bond credit ratings in subnational governments. ${ }^{71}$ Not surprisingly, due to the strong presence of first order autocorrelation, as credit ratings $t_{t-1}$ are a significant predictor of current ratings. Other factors, such as spending levels of sates, overall economic development, and population are statistically negligible.

\section{Checks for nonlinearity}

As our interaction models in table 2 assume a constant, linear effect of corruption moderated by transfers, we check to see if that assumption holds, or whether the interaction is in fact non-linear. Our anticipation is that corruption has a negative effect on credit ratings at low levels of federal dependence, yet is negligible at higher levels.

We take a pragmatic approach to testing this via splitting our sample into four ranked quartiles according to a state-year's level of fiscal federal dependence throughout the sample. Quartile 1 represents those state-years with the lowest levels of dependence, while quartile 4 represents the highest dependence. We run both fixed and random (2-stage instrumental) models for each sub-sample, reported in table 3 . As anticipated, we find that the effect of corruption on credit ratings is indeed nonlinear in that the significance levels only apply to low levels of transfers. We find a robust, negative effect of corruption on credit ratings for the bottom quartile (the least federally dependent) for both estimation approaches, while we observe positive, yet statistically negligible effects for the three subsequent quartiles. In addition to the split-sample approach we report here, we also employ a nonlinear check of our interaction via an approach developed by Hainmueller, Mummolo, and Xu (2019), found in appendix F. The estimates from their approach are essentially similar to those in table 2.

In substantive terms of the sample, what we observe is that among states with low levels of dependence (in the bottom quartile), we find that states such as Illinois, Massachusetts, and New Jersey have multiple years of higher than average corruption and lower than average credit ratings. While conversely, low dependence sates such as Colorado, Nevada, North Dakota, and Minnesota have low corruption and high credit ratings. Such patterns at this low level of federal dependence elucidate the negative and significant conditional relationship between corruption and credit ratings.

\section{Further robustness checks}

In addition to checking for nonlinearity of our findings for $\mathrm{H} 2$, we explore further checks of robustness (see appendix D). We check for several alternative specifications. First, we check whether our results

\footnotetext{
${ }^{68}$ Depken and Lafountain, 2006; Liu et al., 2017.

${ }^{69}$ Afonso et al., 2011.

${ }^{70}$ Cantor and Packer, 1996; Depken and Lafountain, 2006; Grizzle, 2010.

${ }^{71}$ Pérez-Balsalobre and Llano-Verduras, 2020.
} 
Table 3: The effect of corruption at varying levels of federal dependence

\begin{tabular}{|c|c|c|c|c|c|c|c|c|}
\hline \multirow[b]{2}{*}{ Level of federal dependence: } & \multicolumn{4}{|c|}{ Fixed Effects } & \multicolumn{4}{|c|}{ REG2SLS } \\
\hline & $\begin{array}{l}\text { Quartile } 1 \\
\text { (low) }\end{array}$ & Quartile 2 & Quartile 3 & $\begin{array}{c}\text { Quartile } 4 \\
\text { (high) }\end{array}$ & $\begin{array}{l}\text { Quartile } 1 \\
\text { (low) }\end{array}$ & Quartile 2 & Quartile 3 & $\begin{array}{c}\text { Quartile } 4 \\
\text { (high) }\end{array}$ \\
\hline \multirow[t]{2}{*}{ Corruption } & $-0.37^{\star \star}$ & 0.06 & 0.21 & 0.11 & $-0.37^{\star \star}$ & 0.04 & 0.16 & 0.11 \\
\hline & $(0.19)$ & $(0.15)$ & $(0.15)$ & $(0.11)$ & $(0.19)$ & $(0.20)$ & $(0.15)$ & $(0.11)$ \\
\hline \multirow[t]{2}{*}{ Constant } & 4.80 & -6.31 & -14.57 & 3.27 & 12.61 & -21.28 & -18.33 & 3.97 \\
\hline & $(9.24)$ & $(21.37)$ & $(12.02)$ & $(10.81)$ & $(9.22)$ & $(29.85)$ & $(15.00)$ & $(10.77)$ \\
\hline Obs. & 170 & 179 & 186 & 196 & 153 & 159 & 179 & 190 \\
\hline $\mathrm{R}^{2}$ within & 0.757 & 0.685 & 0.688 & 0.786 & 0.778 & 0.686 & 0.686 & 0.787 \\
\hline$R^{2}$ between & 0.877 & 0.895 & 0.449 & 0.872 & 0.842 & 0.323 & 0.298 & 0.860 \\
\hline $\mathrm{R}^{2}$ total & 0.865 & 0.866 & 0.490 & 0.869 & 0.840 & 0.359 & 0.361 & 0.863 \\
\hline
\end{tabular}

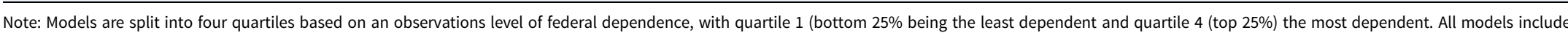

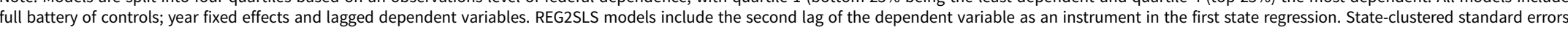
are in parenthesis. ${ }^{* \star *} p<0.01,{ }^{* *} p<0.05,{ }^{\star} p<0.1$. 
for table 2 hold if we include a measure of partisanship. ${ }^{72}$ Namely, we include the partisan affiliation of the state's governor, the president's party affiliation, and whether the two are aligned. Similar to our theory regarding transfers, we would expect that partisan alignment would signal to external creditors that a state is more likely to receive financial backing if they are politically aligned with the federal executive. Table A4 (in appendix D) shows that the main results from table 2 hold in the main fixed effects models, while the effects of partisanship are negligible across the models.

Next, we re-run the models using an alternative dependent variable, namely the two-year moving average of a state's credit rating. ${ }^{73}$ We do this because ratings can be adjusted anytime during a given year, and therefore a yearly summary may lack precision in terms of effects from the explanatory variables. We re-run our tests of $\mathrm{H} 2$ in particular with this dependent variable across our three main specification, and find our original estimates to be robust (see appendix D, table A5).

\section{Conclusion}

This article investigates the link between corruption and subnational creditworthiness. Using data on US states, we show support for our first hypothesis that corruption is largely unrelated to credit ratings in the aggregate sample. However, as per our second hypothesis, we find a clear negative effect of corruption only in states with a comparatively high level of fiscal autonomy. Our results for both hypotheses are robust and consistent across several model specifications and different estimators. This suggests that fiscal dependence allows corrupt subnational units to continue to borrow on favorable terms, and that the federal government is seen to implicitly guarantee the repayment of debt in fiscally dependent states, which shields more dependent states from the negative effects of corruption on credit ratings.

Our findings thereby contribute to the emerging debate on subnational creditworthiness by suggesting that corruption does not always undermine ratings, and that such effects may both shift over time and between contexts. This finding thereby adds some nuance to the emerging consensus on the detrimental effect of corruption on credit ratings. While corruption has important and severe negative consequences for economic performance, some subnational units are still seen as creditworthy and can thereby continue to borrow on favorable terms.

The evidence provided in this study also has implications for the debate on fiscal federalism, decentralization, and the impact of external assistance and aid more broadly. Potentially, fiscal dependence may be a precondition for corruption control and protect taxpayers from assuming an extra cost on debt repayment, as well as uphold vital public services and thereby protect vulnerable groups from being adversely affected by the consequences of corruption and mismanagement. However, favorable credit ratings and low-cost borrowing may also potentially contribute toward insulating corrupt officials from demands for accountability and even empower corrupt governments. Fiscal dependence may, much in line with ideas of external aid "resource curse" literature, lead to a "fiscal illusion" 74 whereby voters see expenditures as disconnected from revenues, since revenues are generated by distant others. In other words, if state-level voters perceive that the cost of local consumption and public service expenditures can be secured without increasing local taxes, they may also not demand accountability for overspending. This allows government to continue to "expand their expenditures while externalizing the costs to others." ${ }^{75}$ Several studies show that corrupt officials seen as competent to secure local economic benefits can induce loyalty among voters and local constituents. ${ }^{76}$ If politicians are convicted for a form of corruption that does not necessarily directly or immediately affect voters, such corruption, sometimes go under the radar of voter punishment. ${ }^{77}$ Corrupt subnational governments may thereby be allowed to continue to "overfish" the common pool resource. ${ }^{78}$

\footnotetext{
${ }^{72}$ See, i.e., Barta and Johnston, 2018.

${ }^{73}$ See Block and Vaaler, 2004.

${ }^{74}$ Wagner, 1976; Oates, 1988.

${ }^{75}$ Rodden, 2006; Von Hagen, 2001; Funashima and Hiraga, 2017.

${ }^{76}$ Fernandez-Vasquez, 2014; Auyero, 2006; Nichter and Peress, 2017; Bauhr and Charron, 2018.

${ }^{77}$ Bauhr, 2017.

${ }^{78}$ Weingast, 2009.
} 
Our findings also suggest several viable avenues for future research. First, it is worth investigating how shaping the composition of different types of federal transfers may have varying effect on keeping corrupt politicians in office. Our data does not allow us to distinguish between different forms of federal transfers, and some types of transfers may more effectively signal bailout expectations. ${ }^{79}$ It would also be interesting to see how our results relate to other indicators of fiscal mismanagement, including, i.e., adherence to the rule of law or the ability of governments to pass the budgets on time. ${ }^{80}$ Second, while we attempt to mitigate potential endogeneity by relying on a dynamic panel with an instrumental estimator and instrumental analyses, ${ }^{81}$ we encourage future research to engage with other approaches to enhance possibilities to make causal inferences. Finally, it could be useful to determine whether the relationship between corruption and subnational creditworthiness in the United States is the same as in other federal countries, such as Canada or Germany.

Supplementary material. To view supplementary material for this article, please visit https://doi.org/10.1017/bap.2020.22.

\section{References}

Abdelal, Rawi, and Mark Blyth. 2015. "Just who put you in charge? We did: CRAs and the politics of ratings." In Ranking the World: Grading States as a Tool of Global Governance, edited by Alexander Cooley and Jack Snyder, 39-59. Cambridge: Cambridge University Press.

Afonso, António, Pedro Gomes, and Philipp Rother. 2011. "Short- and long-run determinants of sovereign debt credit ratings." International Journal of Finance and Economics 16: 1-15.

Ahrend, Rudiger. 2012. “Understanding Russian Regions' Economic Performance during Periods of Decline and growth-An Extreme Bound Analysis Approach.” Economic Systems 36 (3): 426-43.

Ahrend, Rudiger, Marta Curto-Grau, and Camila Vammalle. 2013. "Passing the Buck? Central and Sub-national Governments in Times of Fiscal Stress.” OECD Regional Development Working Papers, No. 2013/05.

Aidt, Toke. 2009. "Corruption, Institutions, and Economic Development." Oxford Review of Economic Policy 25 (2): $271-91$.

Allison, Paul D., Richard Williams, and Enrique Moral-Benito. 2017. "Maximum likelihood for cross-lagged panel models with fixed effects." Socius: 3.

Alt, James E., and David Lassen. 2006. "Fiscal transparency, political parties, and debt in OECD countries." European Economic Review 50: 1403-39.

Alt, James E., and David Lassen. 2012. "Enforcement and public corruption: Evidence from the American states.” The Journal of Law, Economics, and Organization 30 (2): 306-38.

Andersen, Asger L., David D. Lassen, and Lasse H.W. Nielsen. 2010. “The Impact of Fiscal Governance on Bond Markets: Evidence from Late Budgets and State Government Borrowing Costs.” EPRU Working Paper Series: No. 2010-11. University of Copenhagen, Economic Policy Research Unit (EPRU), Copenhagen.

Andersen, Asger L., David D. Lassen, and Lasse H.W. Nielsen. 2012. “Late Budgets.” American Economic Journal: Economic Policy 4 (4): 1-40.

Anderson, T. W., and Cheng Hsiao. 1981. "Estimation of dynamic models with error components." Journal of the American statistical Association 76 (375): 598-606.

Angrist, Joshua, and Jorn-Steffen Pischke. 2008. Mostly harmless econometrics: An empiricist's companion. Princeton, NJ: Princeton University Press.

Archer, Candace C., Glen Biglaiser, and Karl DeRouen Jr. 2007. “Sovereign Bonds and the 'Democratic Advantage': Does Regime Type Affect Credit Rating Agency Ratings in the Developing World?” International Organization 61.

Asongu, Simplice A., and Mohamed Jellal. 2013. "On the channels of foreign aid to corruption." Economics Bulletin 33 (3): $2191-$ 201.

Auyero, Javier 2006. “The Political Makings of the 2001 Lootings in Argentina”. Journal of Latin American Studies 38 (2): $241-$ 65.

Baltagi, Badi H. (ed.). 2013. Econometric analysis of panel data, Fifth Edition. Chichester, West Sussex: John Wiley and Sons, Inc.

Barta, Zsófia, and Alison Johnston. 2018. "Rating Politics? Partisan Discrimination in Credit Ratings in Developed Economies." Comparative Political Studies 51: 587-620.

Barta, Zsófia, and Kristin Makszin. 2020. "The politics of creditworthiness: political and policy commentary in sovereign credit rating reports." Journal of Public Policy: 1-24.

Bastida, Francisco, María-Dolores Guillamón, and Bernardino Benito. 2015. "Fiscal transparency and the cost of sovereign debt." International Review of Administrative Sciences.

Bauhr, Monika. 2017. “Need or Greed? Conditions for Collective Action against Corruption.” Governance 30 (4): 561-81.

\footnotetext{
${ }^{79}$ Hanniman, 2018.

${ }^{80}$ See, i.e., Andersen et al., 2010, 2012.

${ }^{81}$ Baltagi, 2013; Brueckner, Norris, and Gradstein, 2015.
} 
Bauhr, Monika, and Nicholas Charron. 2018. "Insider or Outsider? Grand Corruption and Electoral Accountability." Comparative Political Studies 51 (4): 415-46.

Baum, Anja, Sanjeev Gupta, Elijah Kimani, and Sampawende J. Tapsoba. 2017. “Corruption, taxes and compliance.” Journal of Tax Research 15: 190-216.

Beck, Nathaniel, and Jonathan N. Katz. 1995. "What to do (and not to do) with time-series cross-section data." American political science review 89 (3): 634-47.

Benfratello, Luigi, Alfredo Del Monte, and Luca Pennacchio. 2018. "Corruption and public debt: A cross-country analysis." Applied Economics Letters 25 (5): 340-44.

Berg, Florian, Paula Margaretic, and Sébastien Pouget. 2016. "Sovereign Bond Spreads and Extra-Financial Performance: An Empirical Analysis of Emerging Markets.” Working Papers Central Bank of Chile, 789. Central Bank of Chile.

Biglaiser, Glen, and Johseph L. Staats. 2012. "Foreign Direct Investment in Latin America: The Importance of Judicial Strength and Rule of Law: Foreign Direct Investment in Latin America.” International Studies Quarterly 56 (1): $193-202$.

Biglaiser, Glen, Brian Hicks, and Caitlin Huggins. 2008. "Sovereign Bond Ratings and the Democratic Advantage: Portfolio Investment in the Developing World." Comparative Political Studies 41 (8): 1092-116

Block, Steven A., and Paul M. Vaaler. 2004. "The price of democracy: sovereign risk ratings, bond spreads and political business cycles in developing countries." Journal of International Money and Finance 23 (6): 917-46.

Bordignon, Massimo, and Gilberto Turati. 2009. "Bailing out expectations and public health expenditure." Journal of Health Economics 28: 305-21.

Boylan, Richard T., and Cheryl X. Long. 2003. "Measuring Public Corruption in the American States: A Survey of State House Reporters." State Politics and Policy Quarterly 3 (4): 420-38.

Brueckner, Markus, Era Dabla-Norris, and Mark Gradstein. 2015. "National income and its distribution." Journal of Economic Growth 20: 149-75.

Bruner, Christopher, and Rawi Abdelal. 2005. "To Judge Leviathan: Sovereign Credit Ratings, National Law, and the World Economy." Journal of Public Policy 25: 191-217.

Butler, Alexander W., Larry Fauver, and Sandra Mortal. 2009. "Corruption, municipal connections, and municipal finance." Review of Financial Studies 22 (7): 2873-905.

Cantor, Richard, and Frank Packer. 1996. "Determinants and Impact of Sovereign Credit Ratings." SSRN Electronic Journal.

Caouette, John B. (ed.) 2008. Managing credit risk: the great challenge for global financial markets, 2nd ed. Wiley finance series. Hoboken, NJ: Wiley.

Cavallo, Eduardo, Andrew Powell, and Roberto Rigobon. (2013). "Do credit rating agencies add value? Evidence from the sovereign rating business." International Journal of Finance and Economics 18: 240-65.

Charron, Nicholas, Dijkstra, Lewis, and Lapuente, Victor. 2014. "Regional Governance Matters: Quality of Government within European Union Member States.” Regional Studies 48 (1): 68-90.

Connolly, Michael. 2007. "Measuring the Effect of Corruption on Sovereign Bond Ratings." Journal of Economic Policy Reform 10:4: 309-23.

Cooray, Arusha, Ratbek Dzhumashev, and Friedrich Schneider. 2017. "How Does Corruption Affect Public Debt? An Empirical Analysis." World Development 90: 115-27.

Cordis, Adriana S., and Jeffrey Milyo. 2016. "Measuring public corruption in the United States: Evidence from administrative records of federal prosecutions." Public Integrity 18 (2): 127-48.

Cutler, A. Claire, Virginia Haufler, and Tony Porter (eds.) 1999. Private authority and international affairs, SUNY series in global politics. Albany, NY: State University of New York Press.

Del Monte, Alfredo, and Erasmo Papagni. 2007. "The Determinants of Corruption in Italy: Regional Panel Data Analysis." European Journal of Political Economy 23 (2): 379-96.

Depken, Craig, and Courtney L. Lafountain 2006. "Fiscal Consequences of Public Corruption: Empirical Evidence from State Bond Ratings," Public Choice 126: 1-2, 75-85.

Dilger, Robert Jay. 2019. Federal Grants to State and Local Governments: A Historical Perspective on Contemporary Issues. Washington, DC.

Enderlein, Henrik, Sonja Wälti, and Michael Zürn (eds.). 2010. Handbook on Multi-Level Governance. Cheltenham, United Kingdom, and Northampton, MA: Edward Elgar.

Escolano, Julio, Luc Eyraud, Marialuz M. Badia, Juliane Sarnes, and Anita Tuladhar. 2012. "Fiscal Performance, Institutional Design and Decentralization in European Union Countries." IMF Working Paper 45, International Monetary Fund.

Fernandez-Vazquez, Pablo. 2014. “And Yet It Moves: The Effect of Election Platforms on Party Policy Images.” Comparative Political Studies 47 (14): 1919-44.

Fisman, Raymond, and Roberta Gatti. 2002. "Decentralization and Corruption: Evidence from US Federal Transfer Programs." Public Choice 113 (1-2): 25-35.

Funashima, Yoshito, and Kazuki Hiraga. 2017 "Wagner's law, fiscal discipline, and intergovernmental transfer: empirical evidence at the US and German state levels." International Tax Public Finance 24: 652-77.

Glaeser, Edward L., and Raven E. Saks. 2006. "Corruption in America." Journal of Public Economics 90 (6): $1053-72$.

Grizzle, Cleopatra. 2010. "The impact of budget stabilization funds on state general obligation bond ratings." Public Budgeting and Finance 30 (2): 95-111.

Hainmueller, Jens, Jonathan Mummolo, and Yiqing Xu. 2019. "How Much Should We Trust Estimates from Multiplicative Interaction Models? Simple Tools to Improve Empirical Practice.” Political Analysis 27 (2): 163-92. 
Hall, Rodney B., and Thomas J. Biersteker. 2002. The Emergence of Private Authority in Global Governance. Cambridge: Cambridge University Press.

Hallerberg, Mark. 2011. "Fiscal Federalism Reforms in the European Union and the Greek Crisis." European Union Politics 12 (1): $127-42$.

Hanniman, Kyle. 2018. “Are Transfer-Dependent Governments More Creditworthy? Reassessing the Fiscal Federal Foundations of Subnational Default Risk.” British Journal of Political Science: 1-23.

Hendry, David. 1995. Dynamic Econometrics. Oxford: Oxford University Press.

Hernández-Trillo, Fausto, Ricardo Smith-Ramírez, Eduardo Cavallo, and Tito Cordella. 2009. "Credit Ratings in the Presence of Bailout: The Case of Mexican Subnational Government Debt [with Comments]." Economía 10 (1): 45-79.

Imam, Patrick A., and Davina F. Jacobs. 2007. Effect of Corruption on Tax Revenues in the Middle East. International Monetary Fund.

Johnson, Craig L., and Kenneth A. Kriz. 2005. "Fiscal Institutions, Credit Ratings, and Borrowing Costs." Public Budgeting and Finance 25 (1): 84-103.

Kaufmann, Daniel. 2001. “Can Corruption Adversely Affect Public Finances in Industrialized Countries?” Brookings, November 30. Kerwer, Dieter. 2005. "Holding Global Regulators Accountable: The Case of Credit Rating Agencies.” Governance 18: $453-75$.

Larcinese, Valentino, Leonzio Rizzo, and Cecilia Testa. 2013. "Changing Needs, Sticky Budget: Evidence From The Geographic Distribution of US Federal Grants.” National Tax Journal 66 (2).

Leff, Nathaniel H. 1964. "Economic development through bureaucratic corruption." American Behavioral Scientist 8 (3): 8-14.

Litina, Anastasia, and Theodore Palivos. 2016. "Corruption, Tax Evasion and Social Values." Journal of Economic Behavior and Organization 124 (C): 164-77.

Liu, Cheol., and John L. Mikesell. 2014. "The Impact of Public Officials' Corruption on the Size and Allocation of US State Spending." Public Administration Review 74: (3): 346-59.

Liu, Cheol, Tima T. Moldogaziev, and John L. Mikesell. 2017. "Corruption and State and Local Government Debt Expansion." Public Administration Review 77 (5): 681-90.

Martinez-Vazquez, Jorge, Santiago Lago-Peñas, and Agnese Sacchi. 2017. “The Impact of Fiscal Decentralization: A Survey." Journal of Economic Surveys 31 (4): 1095-29.

Matsaganis, Manos, Chrysa Leventi, and Maria Flevotomou. 2012. "The Crisis and Tax Evasion in Greece: What Are the Distributional Implications?” CESifo Forum 13 (2): 26-32.

Mauro, Paolo. 1995. “Corruption and Growth.” The Quarterly Journal of Economics 110: (3): 681-712.

Mauro, Paolo. 1998. “Corruption and the Composition of Government Expenditure.” Journal of Public Economics 69 (2): $263-79$.

Mellios, Constantin, and Eric Paget-Blanc. 2006. "Which Factors Determine Sovereign Credit Ratings?” The European Journal of Finance 12 (4): 361-77.

Mennillo, Giulia, and Timothy J. Sinclair. 2019. "A Hard Nut to Crack: Regulatory Failure Shows How Rating Really Works." Competition and Change 23 (3): 266-86.

Mo, Pak Hung. 2001. "Corruption and Economic Growth.” Journal of Comparative Economics 29 (1): 66-79.

Nichter, Simeon, and Michael Peress. 2017. "Request Fulfilling: When Citizens Demand Clientelist Benefits.” Comparative Political Studies 50 (8): 1086-117.

North Douglass C. 1981. Structure and Change in Economic History. New York and London: W. W. Norton and Co.

Oates, Wallace E. 1988. "On the nature and measurement of fiscal illusion: A survey." In Taxation and fiscal federalism: Essays in honor of Russel Matthews, edited by Geoffrey Brennan. Canberra: Australian National University Press.

Oto-Peralias, Daniel, Diego Romero-Avila, and Carlos Usabiaga. 2013. "Does Fiscal Decentralization Mitigate the Adverse Effects of Corruption on Public Deficits?” European Journal of Political Economy 32 (2013): 205.

Ozturk, Huseyin. 2014. "The origin of bias in sovereign credit ratings reconciling agency views with institutional quality." The Journal of Developing Areas.

Panizza, Ugo. 2017. The Use of Corruption Indicators in Sovereign Ratings. Inter-American Development Bank.

Pérez-Balsalobre, Santiago J., and Carlos Llano-Verduras. 2020. "Modelling sovereign debt ratings for sub-national governments: The case of Spain before and after the crisis." Empirica.

Pew Research. 2017. "Rainy Day Funds and State Credit Ratings". Pew Charitable Trusts, Rainy Day Funds, and State Credit Ratings, accessed 1 May 2020.

Rajkumar, Andrew Sunil, and Vinaya Swaroop. 2008. "Public Spending and Outcomes: Does Governance Matter?” Journal of Development Economics 86 (1): 96-111.

Richey, Sean 2010. “The Impact of Corruption on Social Trust.” American Politics Research 38 (4): 676-90.

Rodden, Jonathan. 2002. "The dilemma of fiscal federalism: grants and fiscal performance around the world." American Journal of Political Science 46 (3): 670-87.

Rodden, Jonathan. 2006. Hamilton's Paradox: The Promise and Peril of Fiscal Federalism. Cambridge: Cambridge University Press.

Rodden, Jonathan., Gunnar S. Eskeland, and Jennie Litvack. 2003. Fiscal decentralization and the challenge of hard budget constraints. Cambridge, MA: MIT Press.

Rodríguez-Pose, Anders, and Anne Krøijer. 2009. "Fiscal Decentralization and Economic Growth in Central and Eastern Europe." Growth and Change 40: (3): 387-417.

Sharma, Chandan, and Arup Mitra. 2019. "Corruption and Economic Growth: Some New Empirical Evidence from a Global Sample.” Journal of International Development 31 (8): 691-719. 
Shea, Patrick E., and Jonathan A. Solis. 2018. "Leaders, Tenure, and the Politics of Sovereign Credit." International Interactions 44: 294-320.

Sinclair, Timothy J. 2008. The New Masters of Capital: American Bond Rating Agencies and the Politics of Creditworthiness, 1st printing. Cornell Studies in Political Economy. Ithaca, NY: Cornell Paperbacks.

Snyder, Richard. 2001. "Scaling Down: The Subnational Comparative Method." Studies in Comparative International Development 36: 93-110.

Standard \& Poor's. 2002. Local and Regional Governments 2000. New York: McGraw-Hill.

Standard \& Poor's. 2008. Sovereign Credit Ratings: A Primer.Ratings Direct. May 2008.

Svensson, Jakob. 1999. “Aid, Growth and Democracy." Economics and Politics 11 (3): 275-97.

Tanzi, Vito, and Hamid R. Davoodi. 2002. "Corruption, Public Investment, and Growth.” In Governance, Corruption, and Economic Performance, 280-99. Washington, DC: International Monetary Fund, Publication Services.

Troeger, Vera E. 2019. “To P or Not to P? The Usefulness of P-values in Quantitative Political Science Research.” Swiss Political Science Review 25 (3): 281-87.

Vigneault, Marianne. 2010. "Fiscal Decentralization with Regional Redistribution and Risk Sharing." Public Finance and Management 10 (1): 48-79.

Von Hagen, Jurgen. 2001. "Central Bank Operations: Auction Theory and Empirical Evidence." Journal of International Money and Finance 20 (6): 737-41.

Von Hagen, Jurgen, and Barry Eichengreen. 1996. "Federalism, Fiscal Restraints, and European Monetary Union." The American Economic Review 86, no. 2 (1996): 134-38.

Wagner, Richard. 1976. "Revenue structure, fiscal illusion, and budgetary choice." Public Choice (pre-1986) 25: 45.

Weingast, Barry R. 2009. "Second Generation Fiscal Federalism: The Implications of Fiscal Incentives." Journal of Urban Economics 65 (3): 279-93.

Wildasin, David E. 2004. “The Institutions of Federalism: Toward an Analytical Framework.” National Tax Journal 57 (2): $247-72$. World Bank. 1997. Helping Countries Combat Corruption: The Role of the World Bank. Washington, DC: World Bank.

Cite this article: Sychowiec M, Bauhr M, Charron N (2021). Does Corruption Lead to Lower Subnational Credit Ratings? Fiscal Dependence, Market Reputation, and the Cost of Debt. Business and Politics 23, 364-382. https://doi.org/10.1017/bap.2020.22 